\title{
Reporting on Internationalization of Operations, GLOBOP: Design and Management of Global Supply Chains
}

Josefa Mula*

Research Centre on Production Management and Engineering (CIGIP), Polytechnic University of Valencia, Spain

*Corresponding author: Josefa Mula, Research Centre on Production Management and Engineering (CIGIP), Polytechnic University of Valencia, Spain; Tel: 34966528423; E-mail: fmula@omp.upv.es

Rec date: March 04, 2014; Acc date: May 19, 2014; Pub date: May 27, 2014

Copyright: (c) 2014 Mula J, This is an open-access article distributed under the terms of the Creative Commons Attribution License, which permits unrestricted use, distribution, and reproduction in any medium, provided the original author and source are credited.

\begin{abstract}
The research project entitled Design and Management of Global Supply Chains (GLOBOP) focuses on the specific model configuration stages with productive multi location and new productive implantations, which affect the design of productive and logistic systems, and the associated supplier network design. This research project aims to offer a methodological and technical solution for those companies that have begun an internationalization process in recent years (late movers)
\end{abstract}

\section{Introduction}

The need to accomplish international markets development with sophisticated, diverse customer requirements and, at the same time, to put into practice global purchasing strategies that exploit worldwide supplier market opportunities is influencing the way production and logistics networks have to be configured and managed. Fragmentation of productive processes and multilocation of activities have become relevant. This implies that the agents integrating the global supply chain (i.e., distributors, original equipment manufacturers, other manufacturers, suppliers and logistic operators, etc.) have to carry out new operations and supply strategies over national borders to reach optimal levels of quality, flexibility and costs.

The internationalization process is one of the most difficult decision-making processes as it implies numerous risks, mainly for SMES, whose resources are limited. The research project entitled Design and Management of Global Supply Chains (GLOBOP) focuses on the specific model configuration stages with productive multi location and new productive implantations, which affect the design of productive and logistic systems, and the associated supplier network design.

This research project aims to offer a methodological and technical solution for those companies that have begun an internationalization process in recent years (late movers). The general research project objectives are to: a) propose a methodology and associated techniques to analyze and design global networks with productive multilocation, and to design plants, warehouses and supplier networks in the new international contexts that imply contemplating all the economic, social and environmental factors.

The above-mentioned factors, which are not incorporated into the design, are generating delays in implantations, major costs, and even unsuccessful implementations or redesigns; b) develop conceptual models with associated working methods, simulation and optimization decision support tools, and implementation guides to facilitate the design and management of global supply chains; c) provide empirical research from the proposed models and tools.

\section{Key Factors in Design and Management in Global Supply Chains}

The design of a productive and logistics system must fall in line with the company's internationalization business strategy [1]. To this end, it is necessary to make productive and logistic decisions by managing resources and developing competences to accomplish market requirements. Critical decisions when dealing with the design and configuration of a global supply chain are the:

- Localization of supply sources (own and otherwise);

- Strategic role of plants, suppliers and warehouses;

- Integration or fragmentation of productive and logistic operations (production or purchasing decisions);

- Service delivery strategies (supply strategy, production strategy, and purchasing strategy

- Global operations network (distribution network, production network, supplier's network).

Productive and logistic designs must continuously undergo adaption and reconfiguration. Therefore, they must be designed to have the capacity to be modifiable in the near future to consider changes in products, variations in the mix of products, capableflexible-adequate-efficient equipment and technologies, priority operational functions of installations-equipment-people, and contingent action protocols.

These factors and characteristics, which must be developed by global supply chains have been summarized as [2,3]: reactivity, scalability, rapid adjustment of existing systems and efficient production.

In today's economic crisis, characterized by a globalization context, poor demand and financial difficulty, the SMEs located in developed economies are seeking new productive implementations or reconfigurations in their productive and logistic networks to remain competitive.

The internationalization processes of both the business and operations supporting them have especially accelerated in order to cover markets in emerging economies [4]. These productive and 
logistic strategies require a model configured with productive and/or distributed multilocation production, as well as organized direct and inverse logistic flows [5].

The processes and practice to improve and optimize the performance of a productive network have not been sufficiently analyzed [6], especially as far as new productive implementations, and constantly reconfiguring and adapting international manufacturing networks, are concerned [7]. Many SMEs and BUIGs (Business Units of Industrial Groups), which act locally and prosper, fail in foreign markets.

Change in markets means having to develop a new analytical framework from which international specialization is understood. The conventional business theory can offer analytical tools, but it is necessary to adapt them to new operations-based specialization conditions. Likewise, there is the need to reflect on the analytical framework from which new forms of SMEs' internationalization are interpreted. It is therefore necessary to use the distributed or multilocation production concept in supply chain design models; covering several objectives simultaneously; considering productive and logistic decisions together. Moreover, there is: the incorporation of tools into the analysis and design phase which allow robustness and security concepts to be incorporated into reconfigured production plants and supply chains; the provision of comprehensive, effective mathematical models to help management make suitable decisions on internationalization. Some relevant works on these matters are provided in the Table 1 below.

\begin{tabular}{|l|l|l|}
\hline $\begin{array}{l}\text { Reasons for } \\
\text { internationalizatio } \\
\mathrm{n}\end{array}$ & [8-12] & $\begin{array}{l}\text { Access to production in low-cost countries; 2) } \\
\text { productive units close to new markets; 3) } \\
\text { fragmentation of the value chain and redesigning } \\
\text { the value chain to gain an advantage in each plant } \\
\text { and node individually, and to obtain the } \\
\text { coordination synergies of this network; 4) creating } \\
\text { new products and markets with the complete } \\
\text { value of global activities, and using the capacities } \\
\text { of companies in the production network. } \\
\text { Production-purchasing economies of scale and } \\
\text { investment returns, thus extending the life cycle of } \\
\text { articles in other markets. }\end{array}$ \\
\hline $\begin{array}{l}\text { Internationalizatio } \\
\mathrm{n} \text { phases }\end{array}$ & {$[13,7]$} & $\begin{array}{l}\text { Sporadic exports; exports with independent } \\
\text { agents and/or exports with own commercial } \\
\text { delegations; implementing a shared productive } \\
\text { unit (joint venture); implementing productive units. } \\
\text { Some authors have added the need to } \\
\text { continuously reconfigure and adapt the global } \\
\text { production and manufacturing network. }\end{array}$ \\
\hline $\begin{array}{l}\text { Possible } \\
\text { configurations for } \\
\text { operations }\end{array}$ & {$[8]$} & $\begin{array}{l}\text { For products in which a rapid response to } \\
\text { consumers can significantly increase sales and } \\
\text { sale prices, it is necessary to make attempts to } \\
\text { carry out all the manufacturing phases as close to } \\
\text { the customer as possible by trying to apply lean } \\
\text { and mass customization principles. For products } \\
\text { with greater sensitivity to price, but which also } \\
\text { require a rapid response (seasonality or volatile } \\
\text { demand) the design phase and productive } \\
\text { process must be jointly located in a nearby area } \\
\text { that offers the lowest shared costs. Commodity- } \\
\text { type products with a high value-weight ratio, } \\
\text { whose long-term demand can be foreseen, must } \\
\text { be located in countries where labor is cheap, even } \\
\text { beyond the sales area. Existing guidelines for } \\
\text { global supply chains design and management are } \\
\text { insufficient to help with design and to set up an } \\
\text { internationalization process of operations. }\end{array}$ \\
\hline
\end{tabular}

\begin{tabular}{|c|c|c|}
\hline $\begin{array}{l}\text { Design models of } \\
\text { supply chains }\end{array}$ & $\begin{array}{l}{[11,14-} \\
16]\end{array}$ & $\begin{array}{l}\text { It is concluded that: (1) hybrid approaches are } \\
\text { mainly adopted, which combine integer-mixed } \\
\text { linear programming or Multiobjective integer- } \\
\text { mixed linear programming with meta-heuristics; } \\
\text { (2) first minimization of costs, or combined with } \\
\text { other customers-based criteria; second, with other } \\
\text { operations-based criteria, these being the main } \\
\text { objectives; (3) more validated models with } \\
\text { numerical examples are proposed than those with } \\
\text { applications with real supply chains; (4) the main } \\
\text { novel aspects of these works relate more with } \\
\text { developing meta-heuristics algorithms than } \\
\text { problems modeling; (5) the main identified } \\
\text { limitations refer to the simple nature of the } \\
\text { modeled problem (one stage, one source, one } \\
\text { product or one planning period, among others). } \\
\text { Other identified limitations include poor } \\
\text { computational efficiency and uncertainties in } \\
\text { parameters like demand not being considered. }\end{array}$ \\
\hline $\begin{array}{l}\text { Need for new } \\
\text { analysis models } \\
\text { and tools }\end{array}$ & $\begin{array}{l}{[7,17,1} \\
8]\end{array}$ & $\begin{array}{l}\text { Supply chain management researchers should } \\
\text { produce comprehensive models or working } \\
\text { frameworks of international manufacturing } \\
\text { systems that help managers design and manage } \\
\text { their networks. } \\
\text { These working models/frameworks should bridge } \\
\text { the gap between production systems (Toyota PS, } \\
\text { Volvo PS, Bosch Siemens PS, etc.) and adjusted } \\
\text { manufacturing programs (lean manufacturing), } \\
\text { which lead to excellence when implemented into a } \\
\text { plant with a stable setting. However, they are not } \\
\text { advantageous in a dynamic market setting and in } \\
\text { new international multilocation contexts, or for } \\
\text { reconfiguring an existing network. }\end{array}$ \\
\hline $\begin{array}{l}\text { Shortcomings in } \\
\text { SMEs }\end{array}$ & [19] & $\begin{array}{l}\text { A Delphi study with } 20 \text { industrial managers } \\
\text { showing that the working methods of SMEs lack } \\
\text { the decisions made in the production networks } \\
\text { design and analysis phase to achieve new } \\
\text { scalable processes for production plant design, or } \\
\text { to develop supplier's networks with a global } \\
\text { purchases strategy. }\end{array}$ \\
\hline
\end{tabular}

Table 1: Relevant aspects of the internationalization of operations

\section{Modeling Techniques and Solution}

In specific terms, and based on the identification of requirements, this project will conceptually characterize and model operations design and management processes in global supply chains, which is the main objective of this project. [12,20,21] developed a conceptual model (GLOBOPE), which will act as a starting point for this research project. Analytical techniques, based on operational research, shall be employed in which linear programming, mixed-integer programming, and particularly Multiobjective mathematical programming, stand out to analytically model global supply chains based on conceptual modeling.

In order to formalize uncertainty, fuzzy mathematical programming techniques will be applied. On the one hand, they can be used to incorporate the epistemic uncertainty or lack of knowledge in input parameters into the analytical models or fuzziness in their objectives [22-24]. On the other hand, fuzzy optimization can be used as a solution technique for Multiobjective mathematical programming models [25-27].

Moreover, meta-heuristics will be most suitable to solve optimization problems with integrality constraints of the variables since they seek many solutions in parallel. Simulation models have been widely used in supply chains $([28-30])$. This project will use 
simulation to do what-if analyses to improve the developed analytical models and algorithms. Finally, the applications of the multiagent systems of [31-33] for validating the proposed models are highlighted.

\section{Acknowledgement}

This research is funded by a Spanish Ministry of Science and Education Project entitled 'Operations Design and Management in Global Supply Chains (GLOBOP)’ (Ref. DPI2012-38061-C02-01).

\section{References}

1. Monczka RM, Handfield RB, Guinipero LC, Patterson JL (2009) Purchasing and Supply Chain Management, 4th ed. South-Western Cengage Learning, EEUU.

2. Holweg M, Pil FK (2004) The second century: reconnecting customer and value chain through build-to-order moving beyond mass and lean production in the auto industry. The MIT Press.

3. Mehrabi MG, Ulsoy A, Koren Y (2000) Reconfigurable manufacturing systems: key to future manufacturing. Journal of Intelligent Manufacturing 11: 403-419.

4. Bartlett C, Ghoshal S (2000) Going global: lessons from late movers, Harvard Business Review, Marzo-Abril, 132-142.

5. De Meyer A, Nakane J, Miller J, Ferdows K (1989) Flexibility: the next competitive battle the manufacturing futures survey, Strategic Management Journal 10: 135-44.

6. Rudberg M (2004) Linking Competitive Priorities and Manufacturing Networks: A Manufacturing Strategy Perspective, International Journal of Manufacturing Technology and Management 6: 55-80.

7. Vereecke A, Van Dierdonck R (2002) The strategic role of the plant: testing Ferdow's model. International Journal of Operations and Production management, 22: 492-514.

8. Ferdows K (1997) Making the Most of Foreign Factories. Harvard Business Review: 73-88.

9. Farrell D (2006) Offshoring: Understanding the Emerging Global Labor Market, Harvard Business School Press.

10. Deresky H (2000) International Management: Managing Across Boarders and Cultures. $3^{\mathrm{a}}$ ed., Prentice-Hall Inc, New Jersey.

11. Mula J, Maheut J, Garcia-Sabater JP (2011) Supply chain network design optimization. Journal of Marketing and Operations Management Research 1: 190-205.

12. Yip GS, Bink AJM (2007) Managing Global Customers: An Integrated approach. Oxford University Press, New York.

13. Errasti A (2013) Global Production Networks: Operations Design and Management, Second Edition. CRC Press.

14. Johansson J, Vahlne JE (1977) The Mechanism of Internationalisation. International Marketing Review, 7: 23-32.

15. Meixell MJ, Gargeya VD (2005) Global supply chain design: A literature review and critique. Transportation Research Part E: Logistics and Transportation Review, 41: 531-550.

16. Shen Z (2007) Integrated supply chain design models: A survey and future research directions. Journal of Industrial and Management Optimization, 3: 1-27.

17. Hammami R, Frein Y, Hadj-Alouane AD (2008) Supply chain design in the delocalization context: Relevant features and new modeling tendencies. International Journal of Production Economics 113: 641-656.
18. Mediavilla M, Errasti A (2010) Framework for assessing the current strategic plant role and deploying a roadmap for its upgrading. An empirical study within a global operations network. In: Proceedings of APMS 2010 International Conference on Advances in Production Management Systems, Cernobbio, Italy, 11-13 october.

19. Shi Y (2003) Internationalisation and evolution of manufacturing systems: classic process models, new industrial issues, and academic challenges. Integrated Manufacturing Systems 14: 357-368.

20. Errasti A, Egana MM (2009) Internationalization of operations. Prior art, Cluster mobility, logistics and transportation, San Sebastian.

21. Errasti A (2011) International Manufacturing Networks. Global Operations Design and Management. Servicio Central de Publicaciones del Gobierno Vasco.

22. Martinez S (2013) Framework for configuring production and logistics networks of SMEs and SBUs within an internalization process. Phd Thesis. TECNUN. Universidad de Navarra, Spain.

23. Mula J, Peidro D, Poler R (2010) The effectiveness of a fuzzy mathematical programming approach for supply chain production planning with fuzzy demand. International Journal of Production Economics 128: 136-143.

24. Mula J, Poler R, García JP (2008) Capacity and material requirement planning modelling by comparing deterministic and fuzzy models. International Journal of Production Research, 46: 5589-5606.

25. Peidro D, Mula J, Poler R, Verdegay J (2009) Fuzzy optimization for supply chain planning under supply, demand and process uncertainties. Fuzzy Sets and Systems 160: 2640-2657.

26. Peidro D, Díaz-Madroñero M, Mula J (2009) Operational transport planning in an automobile supply chain: an interactive fuzzy multiobjective approach. In: Recent advances in computational intelligence, man-machine systems and cybernetics 22: 121-127.

27. Peidro D, Mula J, Alemany MME, Lario FC (2012) Fuzzy multi-objective optimization for master planning in a ceramic supply chain. International Journal of Production Research 50: 3011-3020.

28. Díaz-Madroñero M, Peidro D, Vasant P (2010) Vendor selection problem by using an interactive fuzzy multi-objective approach with modified S-curve membership functions. Computers \& Mathematics with Applications 60: 1038-1048.

29. Campuzano F, Mula J (2011) Supply Chain Simulation: A System Dynamics Approach for Improving Performance. Springer.

30. Campuzano F, Mula J, Peidro D (2010) Fuzzy estimations and system dynamics for improving supply chains. Fuzzy Sets and Systems 156: 1530-1542.

31. Mula J, Campuzano-Bolarin F, Diaz-Madroñero M, Karpio KM (2013) A system dynamics model for the supply chain procurement transport problem: Comparing spreadsheets, fuzzy programming and simulation approaches. International Journal of Production Research 51: 4087-4104.

32. Hernández JE, Poler R, Mula J, De La Fuente D (2010) Collaborative tactical planning in multi-level supply chains supported by multiagent systems. In: Balanced Automation systems for Future Manufacturing Networks, Springer: 260-267.

33. Hernández JE, Mula J, Poler R, Pavón J (2011) A multiagent negotiation based model to support the collaborative supply chain planning process. Studies in Informatics and Control 20: 43-54. 